\title{
THE GENETIC BASIS FOR RESISTANCE AND SUSCEPTIBILITY TO SALMONELLA AERTRYCKE IN MICE ${ }^{1}$
}

\author{
H. O. HETZER \\ Iowa State College, Ames, Iowa \\ Received November 2, 1936
}

INTRODUCTION

\begin{abstract}
$\mathbf{A}^{\mathrm{L}}$ LTHOUGH considerable progress has been made in recent years in demonstrating the importance of hereditary factors in resistance to bacterial diseases in animals, relatively little is known about its mode of inheritance. The question is one of obvious importance, for it is only through a knowledge of the part played by heredity that problems bearing on the nature of resistance and susceptibility will eventually be solved. The development of strains of animals distinctly different in their reaction to a particular disease should provide indispensable material for subsequent investigations of such problems.

The experiments reported are based on earlier studies of Schотт (I932). He showed that the resistance of a strain of mice to controlled doses of a Salmonella aertrycke culture could be greatly increased by selective breeding. Furthermore, it was shown that this resistance was largely due to a concentration of heritable factors, and that resistance was at least partially dominant over susceptibility. It was thus the object of this study to determine whether resistance could be further increased by selection, and to investigate more thoroughly the genetic nature of resistance and susceptibility.

Experiments similar to those of SCHOTT were reported by IRwIN (I929) on rats and by LAMBERT and KNOX (I932) on chickens. The increased resistance of rats to the Danysz bacillus and of chickens to fowl typhoid was attributed largely to an accumulation of multiple genetic factors through selection. Roberts and CARD (1926, 1935) showed that resistance to bacillary white diarrhea in chickens is definitely influenced by genetic factors. Webster (1924, 1925, 1933) presented clear-cut evidence that resistance to paratyphoid-enteritidis infection in mice could be increased or diminished by selective breading, resistance and susceptibility being governed by multiple genetic factors. Cole (1930) reported that lines of rabbits selected for resistance and susceptibility to Brucella abortus exhibited wide differences in response to inoculations with this organism. Later it was shown by MANRESA (1932) that resistance to infectious abortion in this species could be accounted for on a single gene basis.

Tyzzer (19I7) and Hagedoorn-LaBrand and Hagedoorn (I g20) observed that the Japanese waltzing mouse was more susceptible to certain

1 Journal Paper No. J372, Iowa Agricultural Experiment Station, Project 252.

Genetics 22: 264 Mar. 1937
\end{abstract}


infections than other stocks of the laboratory mouse. Among various inbred strains of guinea pigs WRIGHT and LEWIS (I92I) noted distinct differences of reaction to tuberculosis. PRITCHETT (1925) obtained similar results for the reactions of various inbred strains of mice to mouse typhoid. Gowen and SCHOTT (I933a) assumed a monofactorial difference between resistance and susceptibility to Bacillus piliformis in mice. The same authors (r933b), by the use of a genetic technique involving double matings in mice, presented clear evidence of the importance of genetic factors in resistance to mouse typhoid.

Further evidence of the part played by heredity in disease resistance has been reviewed by CREW (1928), Kozelka (1929) and others. For a detailed review of the more important work the reader is referred to a report by HILL (1934).

\section{MATERIALS AND METHODS}

At the outset of this investigation in $\mathbf{I} 93 \mathbf{I}$, the strains of mice available were the Silver (Sil) strain, and the Selected resistant (S) stock. A line of the Bagg albino (Ba) strain was obtained in 1933 through the courtesy of Dr. E. C. MACDOWELL of the Carnegie Institution of Washington. The Sil strain originally came from England and was carried as a pen-inbred line in our laboratory until I932. It has since been maintained by brother sister and parent-offspring matings. The $\mathrm{S}$ stock had been developed by Dr. R. G. Sснотт from an unselected random bred strain obtained from a fancier in 1927 . The $\mathrm{Ba}$ strain has been maintained almost exclusively by brother-sister and parent-offspring matings and together with the Sil strain has furnished progeny for test throughout the greater part of the experiment. Particular care was exercised at all times to keep environmental factors in the mouse colony as uniform as possible.

A culture of Salmonella aertrycke was obtained through the courtesy of Dr. Sснотт. According to ScHotт (1932) this organism had exhibited a high stage of virulence over about three years of monthly transfers on veal infusion agar slants. In the present investigation the organism was given one passage through a susceptible host, and the reisolated culture used for four months. It was then replaced by another subculture grown exclusively on veal infusion medium. Each of the cultures has been carried by monthly transfers on veal infusion slants.

During the first three years the inoculum for each test period was prepared with sterile physiological salt solution. A medium containing 0.85 percent salt plus 0.05 percent Difco Bacto Peptone was used during the remainder of the experiment. In preparing the inoculum the growth from two or three 18 -hour cultures was suspended in about $5 \mathrm{cc}$ of the suspension medium and transferred to a serum bottle. A small sample was then drawn 
from the bottle, the number of organisms determined by means of a Gates nephelometer, and dilutions made so that the desired number of organisms was contained in $0.25 \mathrm{cc}$ of the diluent.

At the age of about 60 days all animals to be tested were weighed, and transferred to the isolation laboratory. Injections were made intraperitoneally, and deaths recorded once each day over a period of 2 I days.

\section{EFFECT OF VARIOUS DEGREES OF INFECTION ON THE CONTROL STOCKS}

One of the important conditions in a genetic analysis of resistance to bacterial disease is that the pathogenicity of the infective agent should remain uniform. With a constant pathogenicity, any variations in mortality may be attributed largely to the number of bacteria injected and to the level of resistance of the host.

To test the constancy of the pathogenicity and to determine the effect of administering different numbers of the organism, animals from the Sil and $\mathrm{Ba}$ strains were inoculated at various intervals with doses of $5 \times 10^{4}$ and $2 \times 10^{5}$ organisms.

A comparison between the two doses (see table I) shows that in the Sil strain only there was a slight increase in mortality with increase in dosage. The slightly higher mortality of the Ba strain under the $5 \times 10^{4}$ dose, although not in accord with the results for the Sil strain, may be ascribed to the small number of animals used. These results show that, as far as the two doses are concerned, the number of bacteria injected had no appreciable effect on the mortality of the animals tested, and that the mortality of the two strains was practically identical under similar dosage.

It should be emphasized that the high percentages of death in each strain do not point to any appreciable variability in pathogenicity of the organism. Since the mortality of separate groups of animals injected at various intervals was practically the same throughout, it is probable that the small number of survivors observed in each strain was due to causes other than any marked changes in pathogenicity. It may be that the survivors were more resistant genetically than the non-survivors, but no evidence is available to support this assumption.

\section{RESULTS OF SELECTION FOR RESISTANCE}

The initial selection in this experiment was made by injecting progenies of fifth and sixth generation animals of the selected stock developed by Schotr (1932) with a dose of $5 \times 10^{4}$ organisms. Survivors were used as progenitors of the sixth and seventh generations respectively. All seventh generation progenies were injected with the $5 \times 10^{4}$ dose. In subsequent generations doses of $2 \times 10^{5}, 2 \times 10^{6}$, and $1 \times 10^{7}$ organisms were used to increase the effectiveness of selection. Except for the ninth and fourteenth 


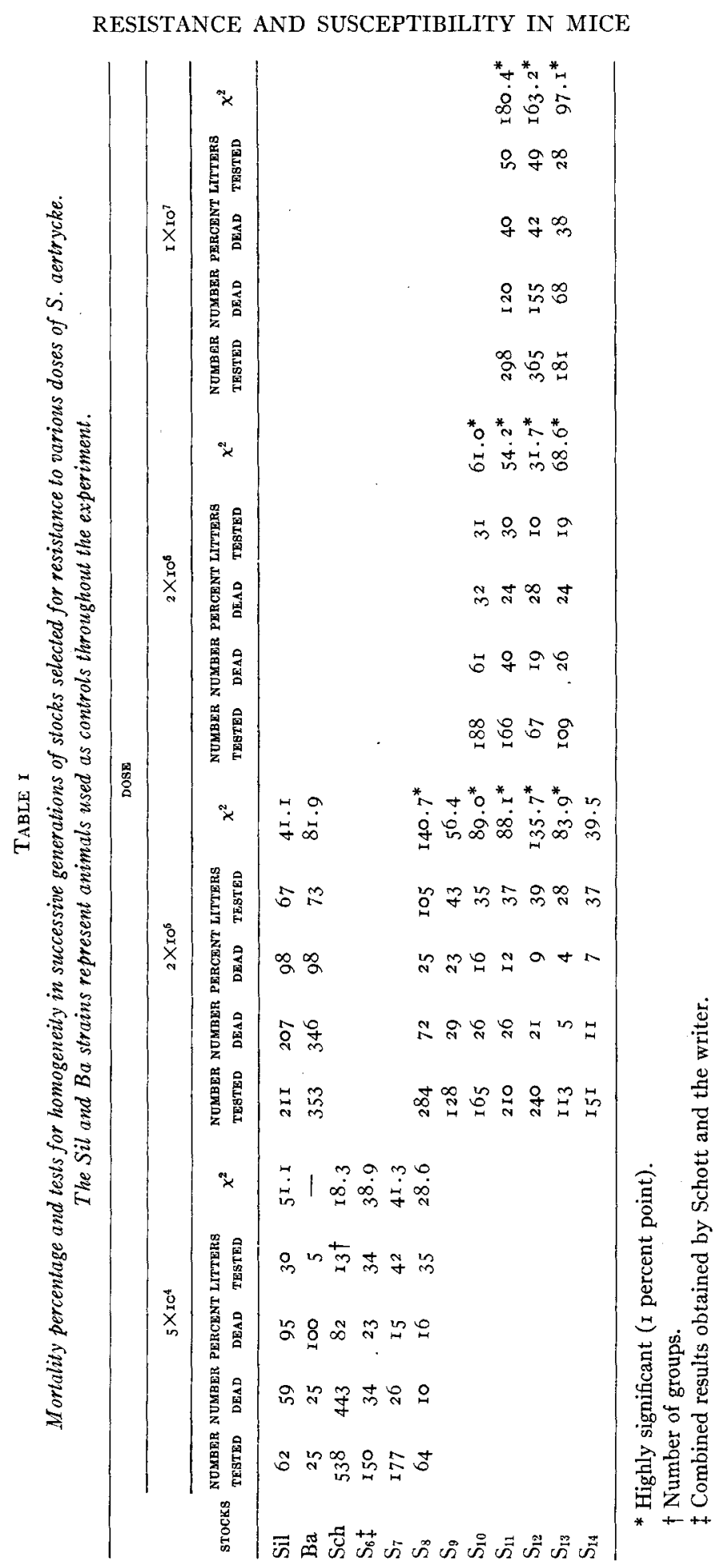


generations, animals to be tested were divided into two or three groups, each injected with a different dose. In the fourteenth generation only the $2 \times 10^{5}$ dose was used. Beginning with the ninth generation the animals chosen for breeding were those survivors whose parents had previously produced offspring with a high level of resistance under one or the other of the larger doses.

Table I gives a summary of the results of selection, together with the mortality record of the Schwing (Sch) foundation stock, as reported by ScHot (1932). The system of naming the stocks is essentially the same as that previously used in our laboratory; progenies of survivors in successive generations are designated as $\mathrm{S}_{7}, \mathrm{~S}_{8}$, etc; litters of matings between animals of different generations are recorded in the generation above the higher numbered parent, for example a litter of $S_{7} \times S_{8}$ animals is included among $S_{9}$ generation progenies of $S_{8} \times S_{8}$ matings.

If the reaction of the Sch stock is taken as a basis for evaluating the effectiveness of selection, it appears that with the $5 \times 10^{4}$ there was a marked decrease in mortality up to the $S_{7}$ generation. In $\mathrm{S}_{8}$ the mortality was slightly but not significantly ${ }^{2}$ higher than in $\mathrm{S}_{7} . \mathrm{S}_{8}$ progenies injected with the $2 \times 10^{5}$ dose gave a higher mortality than those tested with the $5 \times 10^{4}$ dose. By using the $2 \times 10^{5}$ dose in subsequent generations, the mortality percentages again showed a progressive decrease, with but a slight increase in $\mathrm{S}_{14}$. Further increases in the number of bacteria were accompanied by markedly higher mortalities than those of similar groups injected with the $2 \times 10^{5}$ dose, and also by less consistent downward trends of mortalities.

Following injection of the $2 \times 10^{5}$ dose the only significant differences between groups in consecutive generations are those for $S_{9}$ and $S_{10}$, and $S_{12}$ and $S_{13}$. However, the differences between $S_{8}$ and $S_{10}, S_{9}$ and $S_{11}, S_{10}$ and $S_{12}$ and $S_{11}$ and $S_{13}$ cannot be attributed to chance. Hence, there is no reason to doubt that selection was the chief factor responsible for the decrease in mortality in successive generations.

Considering the groups in which the two largest doses were used, only the differences between the $S_{10}$ and $S_{11}$ and the $S_{10}$ and $S_{13}$ generations under the $2 \times 10^{6}$ dose are significant. Were these groups to be considered alone, no safe argument for the effect of selection could be offered. However, their apparent similarity in no way invalidates the conclusion that selection was still effective in enhancing resistance.

Table I shows also that the differences between the various doses are highly significant for the several comparisons possible within each of the

\footnotetext{
${ }^{2}$ The term significant, as used in this paper, is based on the standard error method of comparing mean differences. Detailed tabular material on tests involving analyses of differences is on file at the Iowa State College Library.
} 
generations. This gives statistical support to the conclusion that the reaction of similarly selected groups was in large part affected by the number of bacteria injected.

It is of interest to compare the daily mortality percentages of animals subjected to different doses. The death rates for $S_{11}$ (fig. I) in general are typical of those of other generations. The curves show close agreement between the daily death rate and the total mortality under the various doses. This would indicate that animals injected with the larger doses not only suffered a higher mortality than those subjected to a smaller dose, but also that they died more rapidly.

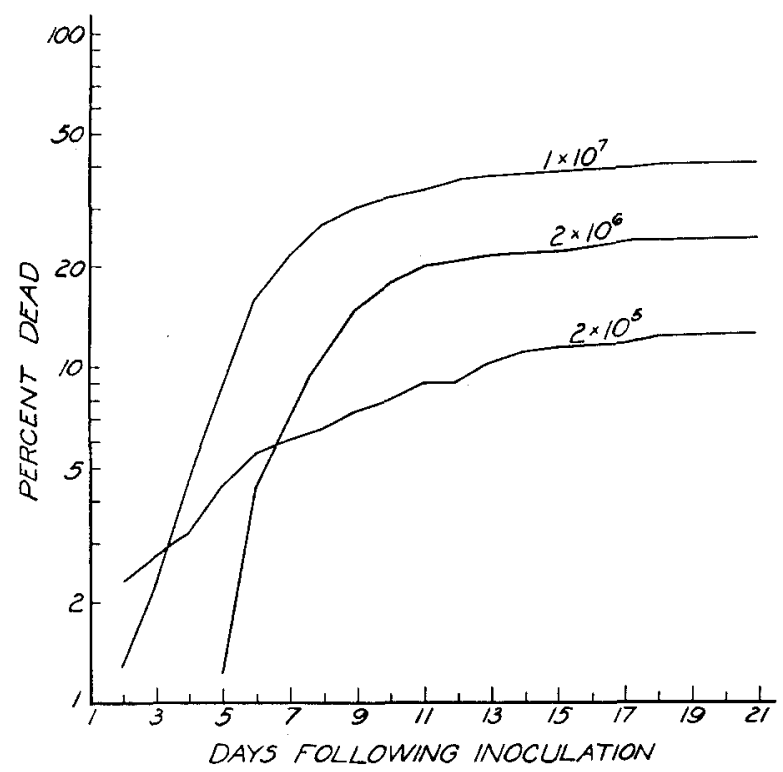

FIGURE r.- Showing effect of injecting different numbers of the organism on mortality rates in the $S_{11}$ generation.

It is now of interest to determine whether the reaction in the variously selected groups was uniform. A method for testing the homogeneity of a set of observations in which the data are expressed in percent has been described by SNEDECOR and IRWIN (I933). Briefly, this method tests whether the probabilities for or against an event in a series of subsamples are distributed around their mean in such a way as would have arisen from random sampling. The resulting value of $\chi^{2}$ (FISHER 1932, p. 104) gives the probability that similar samples drawn from a homogeneous population may be ascribed to chance.

Since for an analysis of this kind the litter represents the most natural unit of subdivision, the data were subdivided according to the number of litters in each of the various groups and analyzed according to the above 
method. The same method of subdivision has been used in subsequent tests.

The values of $\chi^{2}$ (table $I$ ) show that only in $\mathrm{S}_{6}, \mathrm{~S}_{7}$ and $\mathrm{S}_{8}$ under the $5 \times 10^{4}$ dose, and in $S_{9}$ and $S_{14}$ under the $2 \times 10^{5}$ dose is there an indication of a constant probability of death. In the remaining groups the variability in mortality from litter to litter is too large to be attributed to chance fluctuations. Evidence that some, at least, of the observed variations in litter mortality were due to dissimilarities in the ability of survivors to transmit resistance to their offspring will be presented below.

The above results are in close agreement with the observations of SсHотт (1932). On the basis of his findings, the effect of selection in this experiment seems due to a further concentration of genetic factors for resistance. The continued progress made through selection undoubtedly was due to the greater efficiency of the larger doses in eliminating the genetically more susceptible animals.

\section{A CONSIDERATION OF THE INFLUENCE OF ACQUIRED IMMUNITY}

The data just presented show that selection over a series of generations may decrease the mortality of animals subjected to controlled doses of the organism. The problem arises whether some of this decrease in mortality was due to a transfer of passive immunity, rather than to an accumulation of heritable factors for resistance. Although the continued decrease in mortality in successive generations would seem to invalidate any great influence of an acquired immunity, a test series of reciprocal crosses was made between survivors of the later generations of selection and members of the susceptible Sil and Ba strains. The results are given in table 2 .

TABLE 2

Comparative mortality of progenies from reciprocal crosses between survivors of the $S$ stock and the Sil and Ba strains. All progenies were injected with the $2 \times 10^{5}$ dose.

\begin{tabular}{|c|c|c|c|}
\hline MatiNGS & $\begin{array}{c}\text { NUMBER } \\
\text { INJECTED }\end{array}$ & $\begin{array}{l}\text { NUMBER } \\
\text { DEAD }\end{array}$ & $\begin{array}{c}\text { PERcent } \\
\text { DEAD }\end{array}$ \\
\hline $\mathrm{So}^{7} \sigma^{\top} \times \mathrm{Sil} \%$ \% & 88 & IO & I I \\
\hline Silo $\sigma^{7} \times \mathrm{S} \% \%$ & 133 & 28 & $2 \mathrm{I}$ \\
\hline $\mathrm{S} \sigma^{7} \sigma^{\top} \times \mathrm{Ba}+$ ㅇ & 53 & 8 & I 5 \\
\hline $\mathrm{Ba} \sigma^{7} \sigma^{\top} \times \mathrm{S}$ 우우 & 40 & 8 & 20 \\
\hline
\end{tabular}

In both instances males of the S stock produced progeny which gave a somewhat lower mortality than that of the progeny of $S$ females. This in itself is adequate proof against the transmission of passive immunity through surviving females, for as far as is known males in mammals are not able to transmit passive immunity to their offspring.

If the greater resistance of the S stock had been due to a latent infection inducing an active immunity in the animals before entering the test, it 
would be difficult to explain the high percentage of deaths given by the Sil and $\mathrm{Ba}$ strains throughout the experiment. In all cases in which Sil and $\mathrm{Ba}$ females were allowed to produce litters from crosses with $\mathrm{S}$ males and with males of their respective strains, decided and significant differences of reaction were found between the crossbred and non-crossbred progeny. The non-crossbred offspring gave mortalities practically the same as those found in their parent strains.

\section{INBREEDING IN THE SELECTED STOCK}

In an experiment of this sort, in which a relatively small number of animals is used for breeding in each generation, and in which no outside blood is introduced, some inbreeding is inevitable. Since mating of closely related animals in the earlier selected generations did not lead to a decline in vigor, selection was combined with a system of close inbreeding, so as to insure a more rapid fixation of genes for resistance. Occasionally, however, a few matings were made between animals other than parent and offspring or brother and sister.

As inbreeding tends toward the establishment of homozygosis, an inbreeding program based on rigid selection should automatically fix some combination of genes for resistance, thereby leading to a more uniformly reacting host population. If, on the other hand, there were a tendency for inbreeding to fix genes unfavorable for resistance before selection could operate, increased variability would be an inevitable consequence. Inasmuch as most of the selected generations did not exhibit a uniform probability of death, it should be determined whether the inbreeding accompanying selection had an effect on the reaction of the animals in the experiment. On this basis more intensely inbred animals would be most likely to show a higher mortality. Table 3 gives the average inbreeding coefficients (by the method of WRIGHT 1923) in successive generations together with their mortality percentages.

Taking the uniform increase of the inbreeding coefficients as an index of the gradual trend toward homozygosis, more than three-fourths of all genes heterozygous in the foundation stock would be expected to become fixed in the more advanced generations. If selection favored survival of animals more heterozygous than the average of their generation, then the actual degree of homozygosis in any generation would be less than that indicated by the coefficients. If, on the other hand, the rate of fixation were heightened through the selection of animals more homozygous than the average of their generation, then the homozygosis would be higher than that estimated from the coefficients of inbreeding. While there is no means of determining whether the amount of homozygosis in any of the generations was higher or lower than that expressed by the coefficients, 
there can be no doubt that some genes were still unfixed in the advanced generations.

TABLE 3

Mortality percentage and percentage inbreeding in consecutive generations of the $S$ stock under various doses of $S$. aertrycke.

\begin{tabular}{|c|c|c|c|c|c|c|c|c|c|c|c|c|}
\hline \multirow[b]{3}{*}{ GENERATION } & \multicolumn{12}{|c|}{ DOSE } \\
\hline & \multicolumn{3}{|c|}{$5 \times 10^{4}$} & \multicolumn{3}{|c|}{$2 \times 10^{5}$} & \multicolumn{3}{|c|}{$2 \times 10^{6}$} & \multicolumn{3}{|c|}{$1 \times 10^{7}$} \\
\hline & $\begin{array}{l}\text { NUMBER } \\
\text { TESTED }\end{array}$ & $\begin{array}{l}\text { PERCENT } \\
\text { DEAD }\end{array}$ & $\begin{array}{l}\text { PERCENT } \\
\text { INBREED- } \\
\text { ING }\end{array}$ & $\begin{array}{l}\text { NUMBER } \\
\text { TESTED }\end{array}$ & $\begin{array}{l}\text { PERCENT } \\
\text { DEAD }\end{array}$ & $\begin{array}{l}\text { PERCENT } \\
\text { TN INBREED- } \\
\text { ING }\end{array}$ & $\begin{array}{l}\text { NUMBER } \\
\text { TESTED }\end{array}$ & $\begin{array}{l}\text { PERCENT } \\
\text { DEAD }\end{array}$ & $\begin{array}{l}\text { PERCENT } \\
\text { INBREED- } \\
\text { ING }\end{array}$ & $\begin{array}{l}\text { NUMBER } \\
\text { TESTED }\end{array}$ & $\begin{array}{c}\text { PERCENT } \\
\text { DEAD }\end{array}$ & $\begin{array}{c}\text { PERCENT } \\
\text { TINBREED- } \\
\text { ING }\end{array}$ \\
\hline$S_{6}$ & 150 & 23 & 42.6 & & & & & & & & & \\
\hline $\mathrm{S}_{7}$ & 177 & 15 & $54 \cdot 1$ & & & & & & & & & \\
\hline $\mathrm{S}_{8}$ & 64 & I6 & 62.6 & 284 & 25 & $62 \cdot 7$ & & & & & & \\
\hline $\mathrm{S}_{9}$ & & & & 128 & 23 & 68.2 & & & & & & \\
\hline$S_{10}$ & & & & 165 & I 6 & 71.6 & I 88 & 32 & $69 \cdot 3$ & & & \\
\hline $\mathrm{S}_{11}$ & & & & 210 & $\mathrm{I} 2$ & $73 \cdot 3$ & I 66 & 24 & 72.9 & 298 & 40 & 72.0 \\
\hline $\mathrm{S}_{12}$ & & & & 240 & 9 & 79.0 & 67 & 28 & $77 \cdot 7$ & 365 & $4^{2}$ & 77.0 \\
\hline $\mathrm{S}_{18}$ & & & & I 13 & 4 & 80.9 & 109 & 24 & 80.7 & $18 \mathrm{I}$ & $3^{8}$ & 80.1 \\
\hline $\mathrm{S}_{14}$ & & & & I 5 I & 7 & 83.9 & & & & & & \\
\hline
\end{tabular}

As to whether the amount of inbreeding had any effect on resistance, it can be said that no evidence for or against such an assumption was obtained from any of the generations examined. In no case was there a tendency for the greater intensities of inbreeding to be associated with the higher or lower mortality percentages, which might have been anticipated from the results in table 3 . It must be concluded, therefore, that the amount of inbreeding, as measured by the inbreeding coefficients, is no criterion of resistance or susceptibility of the animals to the infection. This agrees with the findings of SCHOTT (1932).

\section{VARIATIONS IN RESISTANCE OF PROGENY FROM CERTAIN MATINGS}

In his analysis of the results of the first six generations of selection, Sснотт (1932) showed that much of the progress in the increased resistance of the S stock could be attributed to the high potentialities for heritable resistance carried by certain individuals. It was therefore decided to mate each sire with several females and to base selection on the progeny record of individual matings in each generation.

The rigid selection and long continued inbreeding practiced in the $\mathrm{S}$ stock should produce a definite trend towards uniformity in the reaction of litters from similarly selected animals. However, an analysis of litters of different sires used in each generation gives good reason to believe that even in the more advanced generations there were still marked differences between survivors in transmitting resistance to their offspring. A sum- 
mary is given in table 4 for certain $S_{11}$ and $S_{12}$ sires relative to the reaction of their progeny under the $\mathrm{I} \times 10^{7}$ dose.

TABLE 4

Reaction of progenies from certain $S_{11}$ and $S_{12}$ generation sires following injection of the $1 \times 10^{7}$ dose.

\begin{tabular}{|c|c|c|c|c|c|c|}
\hline & SIRE & $\begin{array}{l}\text { NUMBER } \\
\text { INJECTED }\end{array}$ & $\begin{array}{c}\text { PERCENT } \\
\text { DEAD }\end{array}$ & $\begin{array}{c}\text { NUMBEER OF } \\
\text { LITTERS }\end{array}$ & $\begin{array}{c}\text { NUMBER OF } \\
\text { DIFFERENT DAMS }\end{array}$ & $x^{2}$ \\
\hline \multicolumn{7}{|c|}{$S_{12}$ generation progenies } \\
\hline$S_{11}$ & 7 & 37 & 5 & 6 & 2 & 5.0 \\
\hline $\mathrm{S}_{11}$ & 22 & 42 & 55 & 5 & 3 & II. $5^{*}$ \\
\hline$S_{11}$ & 36 & 19 & 10 & 2 & I & 0.1 \\
\hline$S_{11}$ & 105 & 46 & 48 & 6 & 2 & $18.4 \dagger$ \\
\hline$S_{11}$ & I33 & I 2 & $5^{8}$ & 2 & 2 & $5.6^{*}$ \\
\hline $\mathrm{S}_{11}$ & I47 & 49 & 26 & 5 & 2 & $\mathrm{x} 3 . \mathrm{I} \dagger$ \\
\hline $\mathrm{S}_{11}$ & I6I & 42 & 43 & 5 & 2 & 6.3 \\
\hline $\mathrm{S}_{11}$ & 186 & $3 I$ & 74 & 4 & 3 & $8.5^{*}$ \\
\hline $\mathrm{S}_{11}$ & 187 & $4 \mathrm{I}$ & 88 & 6 & 3 & 6.8 \\
\hline$S_{11}$ & 327 & 14 & $2 \mathrm{I}$ & 2 & 2 & O.I \\
\hline \multicolumn{7}{|c|}{$S_{13}$ generation progenies } \\
\hline$S_{11}$ & 7 & 27 & 37 & 6 & 6 & II.I* \\
\hline$S_{11}$ & 36 & 47 & 60 & 5 & 4 & $16.4 \dagger$ \\
\hline $\mathrm{S}_{12}$ & 24 & 34 & 24 & 5 & 2 & I $2.9 \dagger$ \\
\hline $\mathrm{S}_{12}$ & 46 & 7 & 57 & I & I & - \\
\hline $\mathrm{S}_{12}$ & 208 & 38 & $4 \circ$ & 6 & 4 & $27 \cdot 4 t$ \\
\hline$S_{12}$ & 253 & I 7 & 6 & 2 & $\mathbf{I}$ & I. 2 \\
\hline $\mathrm{S}_{12}$ & 363 & 7 & 0 & I & I & - \\
\hline
\end{tabular}

* Significant ( 5 percent point).

$\dagger$ Highly significant (I percent point).

Among the males which produced $\mathrm{S}_{12}$ progenies, $\mathrm{S}_{11} \mathrm{I} 87$ apparently carried few factors for resistance as evidenced by the high mortality of his offspring from matings to certain of his sisters. Male $S_{11}$ I86, a litter brother of $\mathrm{S}_{11} \mathrm{1} 87$, in matings with his sisters likewise produced progeny which gave a mortality appreciably above that of other groups in the same generation. $S_{12}$ generation progenies from males $S_{11} 7$ and $S_{11} 36$, on the other hand, gave a much lower mortality than that of any other $S_{11}$ sire. Yet, the mortality of the $S_{13}$ progenies of each of the two sires from matings to their daughters was considerably higher, suggesting that their $S_{12}$ offspring did not possess as high a concentration of factors for resistance as were present in each male. This is also indicated by the increased progeny mortality of male $S_{12} 24$, a son of $S_{11} 7$ and males $S_{12} 46$ and $S_{12} 208$, full brothers sired by $S_{11} 36$. In brother-sister matings each of these males produced offspring with a mortality appreciably above that shown by the progeny of their own parents. The progeny record of the remaining sires in the two generations indicates that they also were not alike in their ability to transmit resistance. 
Table 4 shows also the non-uniform reaction of the litters from certain sires in matings with several females. Among the various males there were only four which when mated to more than one female produced a constant probability of death in their offspring (see values of $\chi^{2}$, table 4 ), suggesting that in the remaining matings the females differed among themselves in their potentialities for heritable resistance.

Although it is disconcerting that at this stage of the experiment such marked differences in mortality should still exist, the obvious explanation is that very few if any animals inherited the same combination of genes for resistance, and hence would not be expected to transmit equal resistance to their offspring.

Inasmuch as all breeding animals were survivors of the disease, it is also reasonable to assume that, notwithstanding the effect of selection to favor the retention of animals with high potentialities for resistance, outside influences were an important source of variation and that in some cases they actually favored survival of animals less resistant than others. When mated together animals of this sort in turn might produce progeny with a mortality appreciably above that of the average of the group as a whole. While there is good reason to believe that the relative importance of genetic and non-genetic factors was not constant throughout the course of the experiment, from the purely genetic point of view the results definitely support the belief that very few if any animals were alike in their genes for resistance. It may be argued then that the non-uniform reaction exhibited by most of the selected generations was at least partly due to genetic differences in resistance between similarly selected animals used for breeding.

\section{AGE AND WEIGHT AS FACTORS IN RESISTANCE}

The plan of the experiment called for a constant age of the animals at the time of infection. Since not all animals were injected at the age of sixty days, it was thought desirable to determine whether age, and weight as incidental to age, played an important part in resistance. No significant differences were found between the survivors and non-survivors of any of the generations when tabulated according to weight or age. This result is in line with the findings of Sснотт (I932).

\section{SEX AS A FACTOR IN RESISTANCE}

While no sex differences in reaction of mice to the organism were observed by Sснотт (1932), the data presented in table 5 show that in this experiment males generally were more susceptible than females.

Table 5 shows that there are fifteen groups with a greater proportionate number of deaths among the males and only two with a higher female mor- 
TABLE 5

Tests for homogeneity and comparison of the reaction by sexes in successive selected generations under various doses of the organism.

\begin{tabular}{|c|c|c|c|c|c|c|c|c|}
\hline GENERATION & $\operatorname{DOS} \mathbb{R}$ & & & $\begin{array}{c}\text { PERCENT } \\
\text { DEAD }\end{array}$ & $\begin{array}{l}\text { NUMBER } \\
\text { LITTERB }\end{array}$ & $x^{2}$ & DIFFERUNCE $†$ & $\begin{array}{l}\text { DIFF. } \\
\text { ST. } \mathrm{E} .\end{array}$ \\
\hline$S_{8}$ & $5 \times 10^{4}$ & $\begin{array}{l}\sigma^{7} \\
9 \%\end{array}$ & $\begin{array}{l}83 \\
67\end{array}$ & $\begin{array}{l}26 \\
18\end{array}$ & $\begin{array}{l}33 \\
30\end{array}$ & $\begin{array}{l}34.9 \\
29.6\end{array}$ & $+8.6 \pm 4.4$ & I.9 \\
\hline $\mathrm{S}_{7}$ & $5 \times 10^{4}$ & $\begin{array}{l}\sigma^{7} \sigma^{7} \\
9 \text { क }\end{array}$ & $\begin{array}{l}97 \\
80\end{array}$ & $\begin{array}{l}\text { I3 } \\
\text { I6 }\end{array}$ & $\begin{array}{l}3^{8} \\
3^{8}\end{array}$ & $\begin{array}{l}32.7 \\
40.8\end{array}$ & $2.8 \pm 3.6$ & 0.8 \\
\hline $\mathrm{S}_{8}$ & $5 \times 10^{4}$ & $\begin{array}{l}\sigma^{x} \sigma^{x} \\
9 \text { 운 }\end{array}$ & $\begin{array}{l}33 \\
3 \mathrm{I}\end{array}$ & $\begin{array}{r}30 \\
0\end{array}$ & $\begin{array}{l}26 \\
24\end{array}$ & $\begin{array}{c}28.3 \\
-\end{array}$ & $+30.3 \pm 7.4$ & $4 \cdot 1$ \\
\hline $\mathrm{S}_{8}$ & $2 \times 10^{5}$ & $\begin{array}{l}\sigma^{x} O^{x} \\
\text { 우우 }\end{array}$ & $\begin{array}{l}128 \\
156\end{array}$ & $\begin{array}{l}30 \\
2 I\end{array}$ & $\begin{array}{l}75 \\
86\end{array}$ & $\begin{array}{l}89 \cdot 4 \\
99 \cdot 5\end{array}$ & $+9.3 \pm 4.3$ & 2.2 \\
\hline $\mathrm{S}_{9}$ & $2 \times 10^{5}$ & $\begin{array}{l}\sigma^{x} \sigma^{x} \\
\text { 웅 }\end{array}$ & $\begin{array}{l}60 \\
68\end{array}$ & $\begin{array}{l}32 \\
\text { I } 5\end{array}$ & $\begin{array}{l}32 \\
35\end{array}$ & $\begin{array}{l}37 \cdot 5 \\
44 \cdot 7\end{array}$ & $+16.9 \pm 5.9$ & 2.8 \\
\hline$S_{10}$ & $2 \times 10^{6}$ & $\begin{array}{l}\sigma^{7} \sigma^{7} \\
99\end{array}$ & $\begin{array}{l}90 \\
75\end{array}$ & $\begin{array}{l}19 \\
12\end{array}$ & $\begin{array}{l}30 \\
31\end{array}$ & $\begin{array}{l}43 \cdot 4^{*} \\
70.2 \dagger\end{array}$ & $+6.9 \pm 4.7$ & I. 5 \\
\hline $\mathrm{S}_{10}$ & $2 \times 10^{6}$ & $\begin{array}{l}\sigma^{7} \sigma^{7} \\
9 \text { \& }\end{array}$ & $\begin{array}{r}\mathrm{IO} 4 \\
84\end{array}$ & $\begin{array}{l}42 \\
20\end{array}$ & $\begin{array}{l}30 \\
28\end{array}$ & $\begin{array}{l}44 \cdot 7^{*} \\
44.8^{*}\end{array}$ & $+22 . \mathrm{I} \pm 4.5$ & $4 \cdot 9$ \\
\hline$S_{11}$ & $2 \times 10^{5}$ & $\begin{array}{l}0^{7} 0^{7} \\
89\end{array}$ & $\begin{array}{r}\text { I } 13 \\
97\end{array}$ & $\begin{array}{r}\text { I } 8 \\
5\end{array}$ & $\begin{array}{l}36 \\
34\end{array}$ & $\begin{array}{l}77.0 \dagger \\
37.5\end{array}$ & $+13.4 \pm 3.3$ & $4 \cdot I$ \\
\hline $\mathrm{S}_{11}$ & $2 \times 10^{6}$ & $\begin{array}{l}0^{7} \sigma^{7} \\
9 q\end{array}$ & $\begin{array}{l}9 \mathrm{I} \\
75\end{array}$ & $\begin{array}{l}30 \\
17\end{array}$ & $\begin{array}{l}29 \\
25\end{array}$ & $\begin{array}{l}46 . x^{*} \\
3 \text { I. } 7\end{array}$ & + $22.3 \pm 4.5$ & 2.8 \\
\hline $\mathrm{S}_{11}$ & $\mathrm{I} \times 1 \mathrm{IO}^{7}$ & $\begin{array}{l}\sigma^{7} \sigma^{7} \\
+9\end{array}$ & $\begin{array}{l}148 \\
150\end{array}$ & $\begin{array}{l}43 \\
37\end{array}$ & $\begin{array}{l}43 \\
49\end{array}$ & $\begin{array}{r}94.6 \dagger \\
105.2 \dagger\end{array}$ & $+5.9 \pm 4.6$ & $\mathrm{I} \cdot 3$ \\
\hline $\mathrm{S}_{12}$ & $2 \times 10^{5}$ & $\begin{array}{l}0^{x} 0^{x} \\
99\end{array}$ & $\begin{array}{l}131 \\
109\end{array}$ & $\begin{array}{r}\text { I I } \\
6\end{array}$ & $\begin{array}{l}37 \\
38\end{array}$ & $\begin{array}{l}67.1 \dagger \\
89.7 \dagger\end{array}$ & $+5.9 \pm 2.8$ & 2. I \\
\hline$S_{12}$ & $2 \times 10^{6}$ & $\begin{array}{l}\sigma^{7} \sigma^{x} \\
\text { ㅇ } 9\end{array}$ & $\begin{array}{l}38 \\
29\end{array}$ & $\begin{array}{l}24 \\
34\end{array}$ & $\begin{array}{l}9 \\
8\end{array}$ & $\begin{array}{l}20.6 \dagger \\
20.5 \dagger\end{array}$ & $10.8 \pm 9.1$ & I. 2 \\
\hline $\mathrm{S}_{12}$ & $1 \times 10^{7}$ & $\begin{array}{l}0^{7} \sigma^{7} \\
\text { 우 }\end{array}$ & $\begin{array}{l}201 \\
164\end{array}$ & $\begin{array}{l}5 \mathrm{I} \\
35\end{array}$ & $\begin{array}{l}47 \\
45\end{array}$ & $\begin{array}{l}99.6 \dagger \\
97.0 \dagger\end{array}$ & $+16.5 \pm 3.8$ & $4: 4$ \\
\hline $\mathrm{S}_{13}$ & $2 \times 10^{5}$ & $\begin{array}{l}0^{7} \sigma^{7} \\
+9\end{array}$ & $\begin{array}{l}65 \\
48\end{array}$ & $\begin{array}{l}6 \\
2\end{array}$ & $\begin{array}{l}25 \\
2 \mathrm{I}\end{array}$ & $\begin{array}{l}44.7 \dagger \\
48.0 \dagger\end{array}$ & $+4.1 \pm 3.2$ & $\mathrm{I} \cdot 3$ \\
\hline $\mathrm{S}_{13}$ & $2 \times 10^{6}$ & $\begin{array}{l}\sigma^{7} \sigma^{7} \\
\text { 우 }\end{array}$ & $\begin{array}{l}52 \\
57\end{array}$ & $\begin{array}{l}27 \\
21\end{array}$ & $\begin{array}{l}\text { I } 8 \\
\text { I } 8\end{array}$ & $\begin{array}{l}33.1 \dagger \\
43.3 \dagger\end{array}$ & $+5.9 \pm 6.9$ & 0.9 \\
\hline $\mathrm{S}_{18}$ & $I \times 10^{7}$ & $\begin{array}{l}\sigma^{7} \sigma^{7} \\
q 9\end{array}$ & $\begin{array}{l}95 \\
86\end{array}$ & $\begin{array}{l}44 \\
30\end{array}$ & $\begin{array}{l}26 \\
25\end{array}$ & $\begin{array}{l}46.7 \dagger \\
55.0 \dagger\end{array}$ & $+14.0 \pm 4.8$ & 2.9 \\
\hline $\mathrm{S}_{14}$ & $2 \times 10^{5}$ & $\begin{array}{l}\sigma^{7} \sigma^{7} \\
9 \text { 우 }\end{array}$ & $\begin{array}{l}69 \\
82\end{array}$ & $\begin{array}{r}\text { I } 2 \\
4\end{array}$ & $\begin{array}{l}29 \\
34\end{array}$ & $\begin{array}{l}33 \cdot 7 \\
23 \cdot 3\end{array}$ & $+7.9 \pm 2.9$ & 2.7 \\
\hline
\end{tabular}

* Significant ( 5 percent point).

$\uparrow$ Highly significant (I percent point).

$\ddagger$ Plus signs in front of mean differences denote a higher mortality in males. 
tality. The higher mortality of the males is significant for ten groups, none of the differences in the remaining groups being significant. Even though the sex difference is not in the same direction throughout, on the whole males were slightly more susceptible than females. No satisfactory explanation for the apparent sex difference in resistance is offered.

If we examine the reaction of the various groups by sex, we see that in six groups both the males and the females showed a uniform probability of death as judged by the small values of $\chi^{2}$ for the litters tested. In two groups the reaction of the males was at variance with that of the females. In the remaining groups neither the males nor the females exhibited a uniform reaction.

If the reaction of each group in the selected generations (table $\mathrm{I}$ ) is compared with its reaction by sex, there is no satisfactory basis for assuming that differences in mortality between the sexes were responsible to any appreciable extent for the variability in the behavior of each group as a whole. Only in the $\mathrm{S}_{8}$ generation under the $2 \times 10^{5}$ dose was there a suggestion that the non-uniformity of the group as a whole was due to a sex difference. However, the uniformity of this group when considered by sex may be due to the small number of animals in the litters, rather than to a genuine sex difference. The only other groups in which a disturbance in the probability of death appeared to be associated with sex are those tested with the $2 \times 10^{5}$ and $2 \times 10^{6}$ doses in the $S_{11}$ generation. Here the differential reaction of the males themselves apparently is responsible for the non-uniformity of the groups as a whole. It should be emphasized that while no causal relationship between the behavior of the remaining groups and their reaction by sexes can be established, the difference in resistance of the sexes appears to be indisputable.

\section{INHERITANCE OF RESISTANCE AND SUSCEPTIBILITY}

In order to determine the mode of inheritance of a trait, it is necessary to demonstrate not only that the strains used in crosses give different results under the same environmental conditions, but also that they are genetically uniform. Although in its reaction to infection the $\mathrm{S}$ stock did not appear to meet the latter requirement, nevertheless observations on progenies of crosses between this strain and the susceptible Sil and $\mathrm{Ba}$ strains should give an indication of the genetic nature of resistance and susceptibility. Reciprocal crosses were made between a certain number of $\mathrm{S}_{10}, \mathrm{~S}_{11}, \mathrm{~S}_{12}$ and $\mathrm{S}_{13}$ animals and the Sil and $\mathrm{Ba}$ strains, and between $\mathrm{Ba}$ females and Sil males. All $F_{1}$ progenies were injected with the $2 \times 10^{5}$ dose. Backcross generations were later produced from various types of matings of $F_{1}$ survivors of the $\mathrm{S} \times \mathrm{Sil}$ cross with the Sil and Ba strains. The backcrossed progenies were likewise injected with the $2 \times 10^{5}$ dose. 
A summary of the various $F_{1}$ stocks is given in table 6 . The $F_{1}$ hybrids from $\mathrm{S} \times \mathrm{Sil}$ and $\mathrm{S} \times \mathrm{Ba}$ crosses show much the same reaction, the total mortality being I 7 percent in each group. This is far below the mortality given by their respective susceptible parents and only slightly higher than that of the $S_{10}$ generation under the $2 \times 10^{5}$ dose. The close approach of

TABLE 6

Mortality percentages and tests for homogeneity in $F_{1}$ hybrids from crosses between the $S$, Sil and $B$ a strains.

\begin{tabular}{|c|c|c|c|c|c|c|}
\hline $\begin{array}{l}\text { TYPE CP } \\
\text { MATING }\end{array}$ & $\operatorname{sex}$ & $\begin{array}{l}\text { NUMBER } \\
\text { TESTED }\end{array}$ & $\begin{array}{l}\text { NUMBER } \\
\text { DEAD }\end{array}$ & $\begin{array}{c}\text { PERCENT } \\
\text { DEAD }\end{array}$ & $\begin{array}{l}\text { LITTERS } \\
\text { TESTED }\end{array}$ & $x^{2}$ \\
\hline \multirow[t]{2}{*}{ Sor $\sigma^{\pi} \times$ Sil $q$ q } & $\sigma^{x} \sigma^{x}$ & 38 & 5 & I3 & & \\
\hline & 우 운 & 50 & 5 & 10 & & \\
\hline Total & & 88 & IO & $\mathrm{r} I$ & 18 & $35 \cdot 9^{*}$ \\
\hline \multirow[t]{2}{*}{ Silo ơ XS \& } & $\sigma^{x} \sigma^{x}$ & 62 & 14 & 23 & & \\
\hline & 우 & 71 & 14 & 20 & & \\
\hline Total & & 133 & 28 & $2 \mathrm{I}$ & $2 \mathrm{I}$ & $4^{1} \cdot 5^{*}$ \\
\hline Grand Total & & 221 & 38 & 17 & 39 & $63 \cdot 4^{*}$ \\
\hline \multirow[t]{2}{*}{$\mathrm{S} \sigma^{\top} \sigma^{\top} \times \mathrm{Ba}$ ㅇ } & $\sigma^{7} \sigma^{x}$ & 22 & 5 & 23 & & \\
\hline & $9 \%$ & $3 I$ & 3 & 10 & & \\
\hline Total & & 53 & 8 & $\mathrm{r}_{5}$ & II & 10.3 \\
\hline \multirow[t]{2}{*}{$\mathrm{Ba}^{7} \sigma^{7} \times \mathrm{S}$ 우 우 } & $\sigma^{x} \sigma^{x}$ & 23 & 7 & 30 & & \\
\hline & 우 & I7 & $\mathbf{I}$ & 6 & & \\
\hline Total & & 40 & 8 & 20 & 9 & $7 \cdot 9$ \\
\hline Grand Total & & 93 & I6 & I 7 & 20 & I 8.5 \\
\hline \multirow[t]{2}{*}{ Sil $\sigma^{\top} \sigma^{7} \times \mathrm{Ba}$ 우 } & $\sigma^{7}$ & 76 & 62 & 82 & & \\
\hline & 우우 & 77 & 60 & 78 & & \\
\hline Total & & I 53 & 122 & 80 & 32 & $54 \cdot 3^{*}$ \\
\hline
\end{tabular}

* Highly significant ( ( percent point).

these $F_{1}$ stocks to that of their resistant parent in mortality indicates that some factors for resistance are dominant. Table 6 shows also that the $F_{1}$ hybrids of the Sil $\times$ Ba cross suffered a mortality decidedly below that observed in either parent strain when subjected to the same dosage. This decrease ( 80 percent as compared with 98 percent) is highly significant for both comparisons, and supports the inference that the Sil and $\mathrm{Ba}$ strains possessed some genes for resistance which in combination with each other gave an increased resistance of their offspring. 
The results shown in table 6 also indicate that resistance is transmitted by both sexes. The somewhat lower mortality of the progeny from S males, while significant only for $S \times$ Sil matings, may partly be attributed to the fact that the $\mathrm{S}$ males used in the crosses represented a more highly selected sample than the $\mathrm{S}$ females.

If any major factors for resistance were sex-linked, the mortality of the sexes in the reciprocal hybrids should not be equal. In the XY type of inheritance, the male progeny from males carrying dominant genes for resistance should be more susceptible than the females. Male and female off-

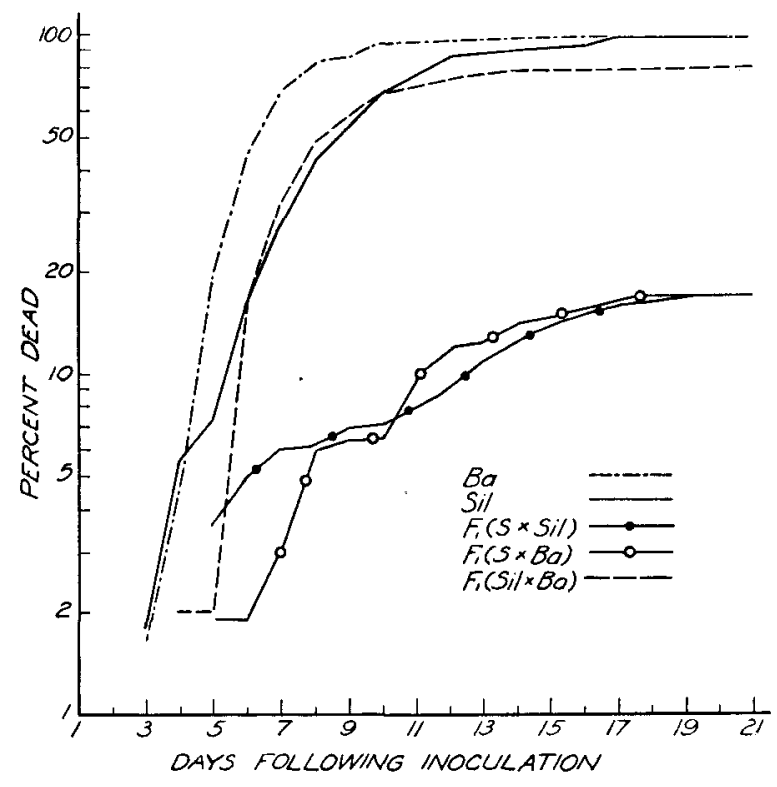

Figure 2.- Mortality curves for $F_{1}$ stocks from crosses between the $S$, Sil and Ba strains. The curves for the Sil and $\mathrm{Ba}$ strains under the $2 \times 1 \mathrm{O}^{5}$ dose are included for comparison.

spring of the reciprocal cross, on the other hand, should show equal resistance. There is no evidence (table 6) that any major gene or genes for resistance are sex-linked. However, there was a tendency toward higher mortality among the male progeny.

The death rates of the various $\mathrm{F}_{1}$ stocks and of those of the Sil and $\mathrm{Ba}$ strains under the $2 \times 10^{5}$ dose are shown in figure 2 . The progenies of the $\mathrm{S} \times$ Sil and $\mathrm{S} \times \mathrm{Ba}$ crosses not only gave a much lower mortality than their respective susceptible parent strains, but the interval to death was also longer in these stocks. The curve for the $\mathrm{F}_{1}$ from Sil $\times \mathrm{Ba}$ suggests as the main difference a delay in initial mortality beyond that of the parent strains.

Mortality records of progenies from reciprocal crosses of $F_{1}$ survivors 
from the $S \times$ Sil cross to the Sil and Ba strains are summarized in table 7 . The total mortality in the two stocks is close to equality, being 53 and 48 percent for the progenies of $\mathrm{F}_{1} \times \mathrm{Sil}$ and $\mathrm{F}_{1} \times \mathrm{Ba}$ crosses respectively. In both cases the mortality of these stocks is decidedly greater than that of the resistant parent stock, but also significantly below that of the susceptible strains. The reaction of each of these stocks simulates a single gene difference between resistance and susceptibility, but there is no satisfactory basis to justify such a conclusion. In view of the non-uniform reaction exhibited by the resistant parent stock as well as by the hybrid stocks (values of $\chi^{2}$, tables 6 and 7 ), and also because of the results of the selection experiment, it would seem that resistance to this organism is probably dependent upon the action of multiple factors.

TABLE 7

Percentages of death and tests for homogeneity in the progenies of crosses between $F_{1}$ hybrids of the $S \times$ Sil cross and members of the Sil and Ba strains.

\begin{tabular}{|c|c|c|c|c|c|}
\hline CROSSES & $\begin{array}{c}\text { NUMBER } \\
\text { TESTED }\end{array}$ & $\begin{array}{c}\text { NUMBER } \\
\text { DEAD }\end{array}$ & $\begin{array}{c}\text { PERCENT } \\
\text { DEAD }\end{array}$ & $\begin{array}{l}\text { LITTERS } \\
\text { TESTED }\end{array}$ & $x^{2}$ \\
\hline $\mathrm{F}_{1}\left(\mathrm{~S} \% \times\right.$ Sil $\left.\sigma^{\lambda}\right) \% \& \times$ Sil $\sigma^{\lambda} \sigma^{\lambda}$ & 262 & I 46 & 55 & 35 & $55 \cdot 2^{*}$ \\
\hline $\mathrm{F}_{1}\left(\mathrm{Sil}\right.$ ㅇ $\left.\times \mathrm{S}^{7}\right) \sigma^{7} \sigma^{7} \times \mathrm{Sil}$ 우 우 & 82 & 40 & 49 & I 8 & 20.0 \\
\hline $\mathrm{F}_{1}\left(\mathrm{Sil} q \times \mathrm{S} \sigma^{7}\right) \%$ ㅇ $\times$ Sil $\sigma^{7} \sigma^{7}$ & 44 & I9 & 43 & 6 & 5.00 \\
\hline Total & 388 & 205 & 53 & 59 & $82.7^{*}$ \\
\hline $\mathrm{F}_{1}\left(\mathrm{~S} \% \times \mathrm{Sil}_{\sigma^{\top}}\right) \circ \stackrel{q}{ } \times \mathrm{Ba}^{\top} \sigma^{\nearrow}$ & 288 & 105 & 36 & 38 & $65 \cdot 3^{*}$ \\
\hline$F_{1}\left(\mathrm{Sil}\right.$ 우 $\left.\times \mathrm{S}^{2}\right) \sigma^{7} \sigma^{7} \times \mathrm{Ba}$ 우 우 & 363 & 216 & 60 & 60 & $94 \cdot 7^{*}$ \\
\hline $\overrightarrow{\mathrm{F}}_{1}\left(\mathrm{Sil}\right.$ 우 $\left.\times \mathrm{S}_{\sigma^{7}}\right)$ 우 우 $\times \mathrm{Ba}^{\top} \sigma^{\top}$ & 84 & 28 & 33 & I I & 6.8 \\
\hline Total & 735 & 349 & 48 & 109 & $200.1^{*}$ \\
\hline
\end{tabular}

* Highly significant ( I percent point).

Examination of the various types of crosses of $F_{1}$ animals with members of the Sil and $\mathrm{Ba}$ strains shows that there are several progeny groups which gave markedly different mortalities. In the case of the backcrosses to the Sil strain the most important feature is that the progenies of $F_{1}$ females of the $\mathrm{S} \% \times$ Sil $\sigma^{x}$ cross gave a mortality significantly above that shown by the progenies of the $F_{1}$ males and females of the reciprocal cross. The results coincide closely with the differences observed in the two $F_{1}$ generations and are indicative of genetic differences in the reciprocal $F_{1}$ hybrids used in the crosses. The difference in mortality of the progenies from $\mathrm{F}_{1}$ males and females of the Sil $\% \times \mathrm{S}_{\sigma^{7}}$ cross is not significant.

The $\mathrm{F}_{1} \times \mathrm{Ba}$ crosses, when compared with the backcrosses to the Sil strain, present a different and more striking situation. Here the progenies of either type of $\mathbf{F}_{1}$ females show a mortality appreciably and significantly below that of the progenies of the $F_{1}$ males. Were one to consider only these crosses, a very good argument for the transmission of passive 
immunity by the $F_{1}$ females could be offered. However, by reference to the $F_{1} \times$ Sil crosses, and in view of the fact that the same $F_{1}$ males and females usually produced offspring in crosses both with the Sil and Ba strains, they furnish no evidence to justify such an assumption. Furthermore, no argument for genetic dissimilarity in the reciprocal hybrids in this case is justified, for the differences are independent of the source of the $F_{1}$ hybrids. Nor is there indication of sex linkage, for in the $F_{1}$ stocks the differences between the sexes are not greater than may be attributed to errors of random sampling.

The cause of the difference between the progenies of the $\mathrm{F}_{1}$ o $\times \mathrm{Ba} \sigma^{7}$ crosses on the one hand, and those of the $\mathrm{F}_{1} \mathrm{o}^{7} \times \mathrm{Ba} \%$ crosses on the other, must thus be sought within the Ba strain. The first possibility would be that the difference between the two types of progeny was due to a cytoplasmic variable. Since, however, the reciprocal $F_{1}$ 's of the $S \times B$ a crosses show no such difference, additional and more critical tests are necessary.

\section{TESTS FOR LINKAGE}

The data from the above crosses also furnish evidence that no major factors for resistance and susceptibility are linked with certain of the color factors in which the strains differed. As already noted, the $\mathrm{F}_{1}$ generation came from matings between the $\mathrm{S}$ and Sil strains and backcrosses were made both to the Sil and $\mathrm{Ba}$ strains. The $\mathrm{S}$ stock contributed the recessive gene for albinism $(c)$, and dominant genes for agouti $(A)$ and non-silver $(S)$. The Sil strain carried the alleles $C, a$, and $s$. The Ba strain was $c c A A s s$. Table 8 gives a classification of the various color segregants relative to their average mortality.

TABLE 8

Tests for linkage between various color genes and any major factors for resistance and susceptibility.

\begin{tabular}{|c|c|c|c|c|c|}
\hline CRoss & \multicolumn{2}{|l|}{ COAT COLOR } & $\begin{array}{l}\text { NUMBER } \\
\text { ANIMALS }\end{array}$ & $\begin{array}{c}\text { NUMBER } \\
\text { DEAD }\end{array}$ & $\begin{array}{c}\text { PERCENT } \\
\text { DEAD }\end{array}$ \\
\hline \multirow[t]{2}{*}{$\mathrm{F}_{1}(C c) \times \mathrm{Ba}(c c)$} & Colored & $(C)$ & 353 & $16_{5}$ & 47 \\
\hline & Albino & (c) & 382 & I 84 & 48 \\
\hline \multirow[t]{2}{*}{$\mathrm{F}_{1}(A a) \times \operatorname{Sil}(a a)$} & Agouti & $(A)$ & I 32 & 70 & 53 \\
\hline & Non-agouti & $(a)$ & I 2 I & 67 & 5.5 \\
\hline \multirow[t]{2}{*}{$\mathrm{F}_{1}(S s) \times \operatorname{Sil}(s s)$} & Non-silver & $(S)$ & 236 & I 22 & $5^{2}$ \\
\hline & Silver & $(s)$ & I 52 & 83 & 55 \\
\hline
\end{tabular}

Were there a relation between the factor for albinism and a major gene or genes for resistance, the albino progeny from $\mathrm{F}_{1} \times \mathrm{Ba}$ crosses should be largely resistant. Actually they gave a slightly, though not a significantly greater mortality than the colored animals. Thus, major genes for resistance segregate independently of the albino factor, 
It is obvious that there is no appreciable difference in mortality between the agouti and non-agouti progeny. The agouti factor therefore exhibits no linkage with any major genes for resistance.

The data from the backcross to the Sil strain may also be arranged to test for independent assortment of $s$ and susceptibility. Since some of the $F_{1}$ animals used in the backcrosses were non-agouti, their progeny may be added to the group used in the linkage test involving silver. If $s$ were linked with genes for susceptibility, the silver progeny from the two types of matings should give a greater mortality than the non-silvers. The proportionate number of deaths is somewhat greater in this group, but the difference is not significant.

In contrast with the results of the first two crosses in table 8 , there was an apparent deficiency of silvers where expectation was a I : I ratio. However, since the silver character is variable, it is probable that low-grade silvers, particularly in the presence of the agouti factor, were sometimes classified as non-silvers. The conclusion regarding independent assortment of the silver factor from a major factor for susceptibility can thus be only tentative, but there is certainly no evidence of close linkage.

\section{ACKNOWLEDGMENTS}

The author wishes to express his sincere appreciation to Drs. E. W. LINDSTROM and W. V. LAMBERT for their constructive criticism and kind encouragement throughout the course of the study, and to Professor G. W. SNEDECOR for suggestions as to the methods of interpretation of the data presented. Acknowledgment is made to the Department of Bacteriology for the use of much valuable material during the early stages of the experiment.

\section{SUMMARY}

This investigation was planned to study the effect of selection for resistance to controlled doses of Salmonella aertrycke in mice and to determine the mode of inheritance of resistance and susceptibility to the disease produced by this organism. The results are based on observations obtained on $5^{\text {I }}$ 2 $^{2}$ mice infected intraperitoneally over a period of three and onehalf years.

Two strains of mice, the Silver (Sil) strain and the Bagg albino (Ba) strain, when tested with controlled doses of the organism showed a high degree of susceptibility throughout the experiment. Their mortality percentages under a dose of $2 \times 10^{5}$ organisms were $9^{8}$ percent in each case.

Selection for resistance was carried out over eight generations beginning with sixth generation progenies of the S stock, previously selected for resistance by Sснотт (1932). There was a continued decrease in mortality in successive generations following injections with the $2 \times 10^{5}$ dose. Ani- 
mals tested with larger doses $\left(2 \times 10^{6}\right.$ and $\left.I \times 10^{7}\right)$ gave a marked increase in mortality as compared with that of animals in the same generations tested with the $2 \times 10^{5}$ dose.

Passive immunity was shown not to play a critical part in the enhanced resistance of the $\mathrm{S}$ stock.

The gradual increase of the coefficients of inbreeding suggests that there $v$.as a definite trend toward homozygosis in the more advanced generations of the selected stock. There was no tendency for animals with higher degrees of inbreeding to give a mortality above that of animals less intensely inbred.

Progeny records of individual matings in later generations of selection gave evidence that there were marked differences in the ability of survivors to transmit resistance to their offspring.

Age and weight, within the limits concerned in this study, were not found to be associated with resistance.

There was some indication of a differential reaction of the sexes, males in most groups being slightly more susceptible than females.

The $F_{1}$ hybrids from crosses between members of the $S$ (resistant) stock and the Sil and Ba strains gave a mortality of $I 7$ percent, which is appreciably below that of their respective susceptible parents and nearly as low as the mortality observed in the resistant stock during the later generations of selection, indicating that some factors for resistance are dominant. The mortality of progenies from the Sil $\times \mathrm{Ba}$ cross was 80 percent. This is significantly below that of either parent strain, suggesting some complementary action of genes for resistance.

Progenies from reciprocal backcrosses of $\mathrm{F}_{1}$ survivors from $\mathrm{S} \times$ Sil matings with the Sil and $\mathrm{Ba}$ strains gave mortalities of 53 and 48 percent respectively. In reciprocal crosses of $F_{1}$ animals with the $\mathrm{Ba}$ strain, the progenies of $\mathrm{Ba}$ females gave a mortality appreciably above that of the progenies of $\mathrm{Ba}$ males, suggesting that the differences were partly due to a cytoplasmic influence transmitted through the Ba females.

There was no indication that any major gene or genes for resistance and susceptibility are sex-linked. Neither did the data suggest linkage with the color genes for albinism $(c)$, non-silver $(S)$ and agouti $(A)$.

In general the results are confirmatory of those of Schotт (I932) and other authors. They suggest that resistance to mouse typhoid is governed by multiple genetic factors.

\section{LITERATURE CITED}

CoLE, L. J., I930 Inheritance of disease resistance in animals. Amer. Nat. 64: 5-I4.

Crew, F. A. E., I 928 Genetical aspects of natural immunity and disease resistance. Edin. Med. Jour. 35: 301-321, 384-404.

FISHER, R. A., 1932 Statistical methods for research workers. 4 th ed. 307 pp. London: Oliver and Boyd. 
Gowen, J. W., and Schorт, R. G., I933a Genetic predisposition to Bacillus piliformis infection among mice. J. Hyg. Camb. 33: 370-378.

1933b A genetic technique for differentiating between acquired and genetic immunity. Amer. J. Hyg. I8: 688-694.

Hagedoorn-LaBrand, A. C., and Hagedoorn, A. L., igzo Inherited predisposition for a bacterial disease. Amer. Nat. 54: $368-376$.

HILl, A. B., I934 The inheritance of resistance to bacterial infection in animal species. A review of the published experimental data. Gr. Brit. Med. Res. Council, Special Report, Ser. I96.

IRwIN, M. R., I929 The inheritance of resistance to the Danysz bacillus in the rat. Genetics I4: $337-365$.

KozELKA, A. W., I929 The inheritance of natural immunity among animals. J. Hered. 20: $5^{\text {I9-- }}$ 530.

LAmbert, W. V., and Knox, C. W., I932 Selection for resistance to fowl typhoid in the chicken with reference to its inheritance. Iowa Agr. Exp. Sta. Res. Bull. I53.

MANRESA, M., I932 Inheritance of resistance and susceptibility to infectious abortion in the rabbit. J. Infect. Dis. $5 \mathrm{I}: 30-7 \mathrm{I}$.

Pritchet, I. W., I925 Microbic virulence and host susceptibility of different strains of mice to per os infection with the type II bacillus of mouse typhoid. J. Exp. Med. 4I : $195-209$.

Roberts, E., and CARD, L. E., I926 The inheritance of resistance to bacillary white diarrhea. Poult. Sci. 6: $18-23$.

I935 Inheritance of resistance to bacterial infection in animals. A genetic study of pullorum disease. Ill. Agr. Exp. Sta. Bull. 4I9.

SchotT, R. G., 1932 The inheritance of resistance to Salmonella aertrycke in various strains of mice. Genetics I7: 203-2 29 .

Snedecor, G. W. and Irwin, M. R., r933 On the chi-square test for homogeneity. Iowa State Col. J. Sci. 8: $75-8$ I

Tyzzer, E. E., I9I 7 A fatal disease of the Japanese waltzing mouse caused by a spore-bearing bacillus (B. piliformis n. sp.). J. Med. Res. 37: 307-338.

Webster, L. T., I924 Microbic virulence and host susceptibility in paratyphoid-enteritidis infection of white mice. IV. The effect of selective breeding on host resistance. J. Exp. Med. 39: $874-886$.

I925 Microbic virulence and host susceptibility in paratyphoid-enteritidis infection of white mice. VIII. The effect of selective breeding on host resistance. Further studies. J. Exp. Med. 42: $1-7$.

1933 Inherited and acquired factors in resistance to infection. I. Development of resistant and susceptible lines of mice through selective breeding. J. Exp. Med. 57: 793-8 7 .

Wright, S., and LewIs, P. A., I92 I Factors in the resistance of guinea pigs to tuberculosis, with special reference to inbreeding and heredity. Amer. Nat. 55: 20-50.

WRIGHT, S., I923 Mendelian analysis of the pure breeds of livestock. I. The measurement of inbreeding and relationship. J. Hered. I4:339-348. 